\title{
Future directions in tissue repair using biomaterials
}

\section{Direcți viitoare în repararea țesuturilor folosind biomateriale}

Defectele complexe ale țesuturilor moi sunt adesea provocatoare pentru a aborda tehnicile reconstructive chirurgicale convenționale. Deși repararea țesuturilor autologere prezintă încă standardul de aur în chirurgia reconstructivă, există situații special când autogrefele nu sunt disponibile. Alogrefele umane rămân o soluție alternativă, dar cu dezavantaje considerabile privind disponibilitatea, reacțiile imunologice și riscul transmiterii bolilor infecțioase. Produsele sintetice utilizate în reconstrucțiile chirurgicale sunt asociate cu rezultate slabe pe termen lung.

Ingineria tisulară s-a dezvoltat pe baza acestor limitări reconstructive. Recent, matricile de țesuturi (scaffold) au fost introduse ca elemente importante în strategiile chirurgicale de reconstrucție a țesuturilor. A fost utilizat un panou mare de matrice extracelulară, cultivat cu diferite populații de celule, iar rezultate promițătoare obținute au fost raportate în repararea complexă a pierderii tisulare, incluzând oasele, mușchii, nervii, vasele sanguine și defectele cutanate. Cercetările viitoare sunt obligatorii pentru standardizarea structurilor de bioinginerie tisulară, pentru a obține cel mai bun rezultat în ceea ce privește restaurarea volumului, recuperarea funcției, integrarea vasculară și stabilitatea pe termen lung a reconstrucției.

Dorim să identificăm domeniul de cercetare care poate fi aplicat cu success în țara noastră, pe baza unei colaborări interdisciplinare între instituțiile medicale, laboratoarele de biologie molecular și institutele de cercetare tehnică. Considerăm foarte utilă promovarea unei strategii pentru repararea țesuturilor moi și imunomodulare folosind progenitori mezenchimali din diferite surse (măduvă osoasă, țesut adipos, sânge din cordonul ombilical) însămânțate pe matrici de țesut solide. Această abordare va spori parteneriatul multiinstituțional, permițând dezvoltarea de noi strategii de reconstrucție pentru pacienții cu defecte de țesut, mai accesibile pentru instituțiile medicale locale, la un cost accesibil și în timp util pentru recâștigarea calității vieții.

Cuvinte-cheie: repararea țesuturilor, biomateriale, ingineria tisulară, celulele stem mezenchimale

\section{Future directions in tissue repair using biomaterials}

Complex soft tissue defects are often challenging to approach using conventional surgical reconstructive techniques. Although autologous tissue repair is still the gold standard in reconstructive surgery, there are particular situations when autografts are not available. Human allografts remains an alternative solution, but with considerable drawbacks regarding availability, immunologic reactions and risk of infectious diseases transmission. Synthetic products used in surgical reconstructions are associated with poor long-term outcomes.

Tissue engineering developed based on these reconstructive limitations. Recently, biological scaffolds have been introduced as important players in surgical strategies of tissue reconstruction. A large panel of extracellular matrices cultured with different cell populations has been used, and promising results were reported in complex tissue loss repair including bone, muscles, nerves, blood vessels and skin defects.

Future research is mandatory to standardize the bioengineered structures, in order to get the best outcome regarding volume restoration, function regaining, vascular integration and long term stability of the reconstruction.

We desire to identify the research area which can be successfully applied in our country, based on an interdisciplinary collaboration between medical institutions, molecular biology laboratories and technical research institutes. We consider very useful to promote a strategy for soft tissue repair and immunomodulation using mesenchymal progenitors from different sources (bone marrow, adipose tissue, umbilical cord blood) seeded on solid scaffolds. This approach will increase the multi-institutional partnership, permitting the development of new reconstructive strategies for patients with tissue defects, more accessible for local medical institutions, with an affordable cost and in appropriate timing for regain the quality of life.

Key words: tissue repair, biomaterials, tissue engineering, mesenchymal stem cells

\section{INTRODUCTION}

A biomaterial is represented by a substance or a combination of biologically inert substances that are used for implantation or integration in a living organism in order to improve or replace specific tissue or organ functions [1].

The use of biomaterials and the development of tissue engineering developed due to impossibility of substituting the tissues or organs affected by various pathologies. Human organ or tissue transplantation remains a standard approach, but there are a series of limitation regarding availability of human donors, immunologic aspects (risk of rejection with subsequent allograft functional impairment or even allograft loss and severe complications associated with long term immunosuppressant therapy) and risk of infectious disease transmission [2].

A specific tissue defect may by approach in different manners, the gold standard being autologous reconstruction due to favorable long-term results in absence of any immunologic response [3]. 


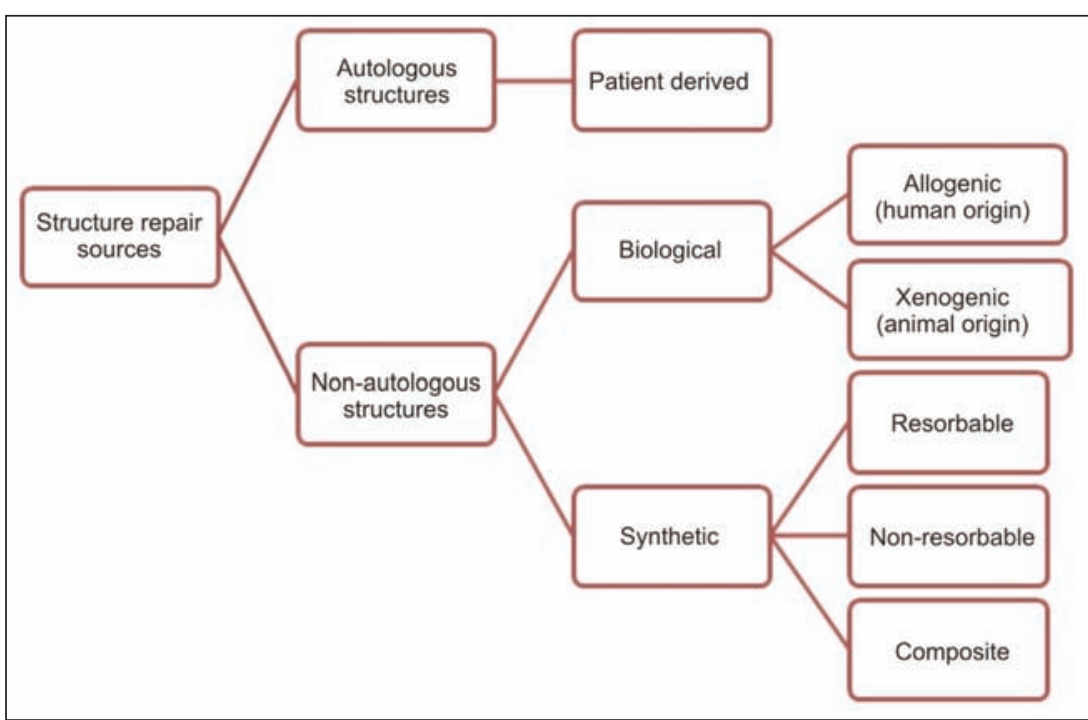

Fig. 1. Reconstructive options

Strict requirements are applied when design a scaffold for in vivo use and it is important to adapt each biomaterial for specific reconstruction, in order to obtain best results regarding durable structural and functional restoration [9].

Key players in regenerative medicine and tissue engineering are scaffolds, cells and cytokines, the essential components of a bioengineered structure [8].

A large panel of extracellular matrices cultured with different cell populations were used with promising results in complex structural and functional repair including defects of skin, bone, muscles, nerves and blood vessels.

Dermal substitutes represent biomatrices that replace the structure

There are situations when patient-derived tissues are not available, due to lack of donor areas, donor site morbidity, or different conditions of the patient that preclude the autologous reconstruction. In these situations other reconstructive options must be chosen, different available possibilities being synthesized in figure 1 [4].

Any structure that is used for tissue reconstruction or replacement has to be very well long-term tolerated by the living organism. The most important requirement for a biomaterial is biocompatibility, ensuring non-cytotoxic effects with favorable properties promoting biofunctionality [5].

Tissue engineering associates elements of biomaterials and cell transplantation in order to substitute affected tissue and also promote structural and functional regeneration. To date, significant progress was noticed in tissue engineering field, resulting in promising therapeutic strategies for organ dysfunction and various tissue loss [6]. Future research is necessary to standardize the bioengineered structures, in order to get the best results regarding volume restoration, function regaining, vascular integration and long term stability of the reconstruction. Three-dimensional designed structures are intensively studied due to their potential to restore more accurate the affected tissue for optimal function [7].

\section{RECONSTRUCTIVE STRATEGIES USING TISSUE ENGINEERING}

In the past, biomaterials were used only for temporary tissue replacing after surgical removal or necrosis. The science of biomaterials evolved and currently, scaffolds are designed similar to natural extracellular matrix in order to support biologic functions, ensuring cellular adhesion, further differentiation and proliferation. Biological scaffolds play an important role for tissue reconstruction [8]. Unlike synthetic materials, biomaterials integrates in the host tissue, release a series of cytokines with anti-inflammatory role, improve healing process and diminish bacterial load [7]. and functions of the dermal layer of the skin. Both acellular and cellular dermal matrices were introduced in clinical practice, patients with various skin defects benefiting from this kind of therapies. Application of a dermal substitute covered by an autologous skin graft ensures the wound coverage and stimulates the healing process in burns, epidermolysis bullosa, piodermagangrenosum, deep chronic wounds, skin ulcers (cause by diabetes, venous insufficiency, neuropathies, pressure ulcers, autoimmune diseases), pathologic scars surgical replacement [7, 10-13]. Acellular dermal matrices have also other indications, in more extensive reconstructions of craniofacial area, cervical region, thorax, breast, abdominal wall including hernia repair or reinforcement of the muscle flaps [7].

Also composite structures resembling human skin were created, consisting of a superficial stratified layer of human keratinocytes and a deep dermal component represented by a collagen scaffold(for example of bovine collagen gel) and cultured human fibroblasts, with good results for venous and diabetic foot ulcers, epidermolysis bullosa, burns and coverage for donor sites of split-thickness graft $[14,15]$.

Tissue engineering is also applied for bone regeneration. Most often large bone defects are replaced by bone grafts, autografts being the golden standard. A wide panel of tissue-engineered constructs was introduced for bone defects, the ideal characteristic of this structures being the resemblance with autografts in terms of composition and biologic properties. Strategies as gene therapy, combinations of scaffolds, healing promoting factors, stem cells and three-dimensional printing could be amazing new tools in treating complex bone defects [16].

Cartilage repair is also a difficult procedure. The main research direction consists in use of biological constructs of cartilage biodegradable scaffolds seeded with adequate cells and growth factors to ensure cellular signaling and interaction [17].

Engineering of the tendons and muscles is also extremely challenging, hard to translate in clinical 
practice, due to the need for restoring both biological structure and mechanical properties with the newdeveloped structures $[18,19]$. Problems still remain in restoration of complete function of an injured tendon, a standardized combination of biological factors is not yet developed and also there is no optimal method to apply the bioengineered construct in the affected area [18].

Another intensively studied field is the development of tissue-engineered nerve grafts for bridging of nerve gaps following complex peripheral nerve injuries for best regenerative performance [20]. Biomaterials that address vascular reconstruction need to meet complex criteria including the same mechanical properties as recipient vasculature, with stabile result, promoting cell growth, production of extracellular matrix and inhibition of thrombus formation [21].

Complex biomedical structures can be adapted for each patient using 3D printing technology. 3D printing shows promising results for complex tissue regeneration including bone, muscles, cartilage vessels and nerves. An indication of this technology is the restoration of cranio-maxillo-facial defects. Also 3D printing may help in organ regeneration, even in challenging micro-architecture like in liver or lymphoid organs [22].

Biomaterial scientists have learned how to mimic the biological systems on different levels. In this direction, nanoscience and nanotechnology will substantially ensure the advance in the field of tissue engineering [23].

Nanotechnologies clearly have influenced the tissue engineering by developing nanomaterials such as carbon nanotubes, nanowires and other inorganic materials. Implanting intelligent nanoscale biosensors within scaffolds will bring more knowledge regarding engineered tissues. Also smart controllable nanorobots could circulate inside the body and repair damaged structures [24].

Another promising direction for the use of biomaterials and nanomedicine is the introduction of smart drug delivery systems with the final goal of improve the therapeutic effects and decrease the side-effects of the substances, resulting in more safer and efficient pharmaceutical agents. Development of performant drug delivery systems is crucial in oncology to ensure a higher tumoricide effect $[25,26]$.

\section{FUTURE DIRECTIONS FOR THE DEVELOPMENT OF CLINICAL APPLICATIONS OF BIOMATERIALS}

We desire to identify the research area which can be successfully applied in our geographic region, based on an interdisciplinary collaboration between medical institutions, molecular biology laboratories and technical research institutes. This approach is based on economic considerations, knowing the limits in implement emerging technologies in developing countries, but having in mind the real benefits of using tissueengineered systems for tissue regeneration.

We consider very useful to promote a strategy for soft tissue repair and immunomodulation using mesenchymal progenitors from different sources (bone marrow, adipose tissue, umbilical cord blood) seeded on solid scaffolds.

Human mesenchymal stem cells were isolated for the first time from bone marrow. Further studies demonstrated a broad spectrum of mesenchymal stem cells origin, including adipose tissue, peripheral blood, amniotic membrane, umbilical cord blood, Wharton's jelly. Mesenchymal stem cells express a specific set of markers on their surfaces: CD73+, CD105+, CD90+ and are negative for CD34, CD14, CD45 and HLA-DR [27, 28].

It was demonstrated that mesenchymal stem cells, trough cytokine secretion and specific receptors, have an important immunoregulatory role, make them particular from other undifferentiated cells and encourage their utilization as part of future cell replacement treatment and also in transplantation field to promote allograft acceptance and transplant tolerance [27].

Research using embryonic stem cells is controversial due to ethical aspects [29]. Fetal/perinatal originated mesenchymal stem cells(derived from placenta, umbilical cord blood, Wharton jelly, amniotic membranes) are an attractive option for regenerative medicine trough their higher proliferative capacity, better differentiation and plasticity, immunomodulatory properties with some genetic features similar of embryonic cells, without any risk of tumorigenicity [28]. Another attractive source of cells for regenerative purpose, recently emerged is human-induced pluripotent stem cells (hiPSCs), with very good properties regarding cell proliferation, cytokine secretion, immunomodulation and ability to modulate the microenvironment trough exosomes and secretion of paracrine factors. The autologous iPSC-derived mesenchymal stromal cells could become in the future an unlimited source of regenerative cells, but sustained research is mandatory in this direction [30].

Adult mesenchymal stem cells originate mainly from bone marrow and adipose tissue, both sources ensuring multipotent stem cells, with the ability to differentiate in a variety of tissue lineages including: cartilage, bone, tendon, adipose tissue, muscle and nervous tissue [31].

The use of bone marrow as adult source of mesenchymal stem cells is the most studied in various research studies. Recently, adipose tissue has been more carefully studied as a potential optimal source of mesenchymal progenitors for use in tissue regeneration.

Since their discovery around 15 years ago, adiposederived stem cells proved their regenerative potential in experimental studies, allowing a safe translation to clinical practice [32-33].

Those cells are obtain from adipose tissue extracted trough liposuction or surgically excised in block that is subsequently processed by filtration and centrifugation and enzymatic digested using collagenase [34-35]. Further, adipose progenitor cells are purified and cultured in specific condition [32]. Adipose derived stem cells can be cultured in the presence of various growth factors on porous scaffolds to engineered 3D constructs and ensure an adequate micro-medium 
for regenerative purposes. Very good results can be obtained with novel collagen-sericin 3D porous scaffolds (with a spongious structure containing $60 \%$ collagen and $40 \%$ sericin) cultured with a dipose precursors, as Dinescu and collaborators described in several studies [36-37].

Besides ex-vivo processing of adipose tissue, clinical use of nanofat grafting technique (consisting of fat injection with very thin needles of even 27 gauges) is also promising for its benefic properties demonstrated in skin rejuvenation. Analysis of nanofat samples revealed a large amount of mesenchymal stem cells in their composition [38].

Based on discussed data, we suggest a therapeutic strategy (figure 2) involving adipose tissue progenitor cells, suitable for tissue defects reconstruction or for immunomodulatory properties in various allograft transplantation.

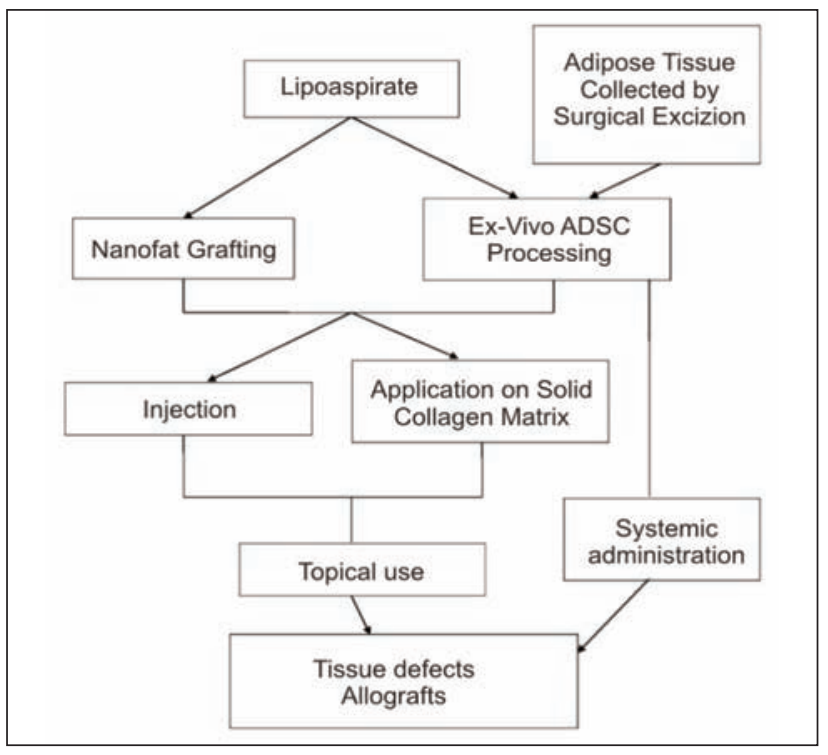

Fig. 2. Therapeutic strategy
This approach will increase the multi-institutional partnership, permitting the development of new reconstructive strategies for patients with tissue defects or need for immune modulation, more accessible for local medical institutions, with an affordable cost and in appropriate timing for regain the quality of life.

Further studies are needed for improve clinical protocols involving bioengineered structures. Stem cells and the creation of microenvironments provide morphogenesis and physical properties. Having, within the patient, a pro-regenerative environment can improve the survival of the engineered graft. Adequate vascularization of any tissue construct is mandatory for its survival and long-term efficacy. In structures with thick scaffolds strategies for stimulate vascularization like angiogenic induction or inclusion of endothelial progenitor cells can be used.

Developing large engineered tissue require a vascularized pedicle to be anastomosed with host vessels. Tridimensional complex scaffolds need a bioreactor model, involving a dynamic system for cell culture [39-40].

\section{CONCLUSIONS}

Important developing in life sciences including stem cell biology, genomics and proteomics contributed to an exponential growth of tissue engineering. Organ and tissue loss led to emerging of therapies that can regenerate tissues and decrease the need of transplantations at least in theory. The desiderate with tissue engineering is to recreate natural healing processes for best structural and functional outcomes. Currently, limitations exist in attempt to develop standardized clinical protocols and also economic considerations. Better-designed bioengineered constructs with affordable technologies may expand the indications in complex tissue defects reconstruction, with minimum morbidity and best results regarding long-term recovery.

\section{BIBLIOGRAPHY}

[1] Bhargava, A.K. Role of ceramics in biomedical applications, In: chapter in Bhargava A.K. Engineering Materials: Polymers, Ceramics and Composites, 2nd edition, PHI Learning, 2012.

[2] Cippà, P.E., Schiesser, M., Ekberg, H., et al. Risk stratification for rejection and infection after kidney transplantation. In: Clinical Journal of the American Society of Nephrology: CJASN. 2015; 10(12), pp. 2213-2220.

[3] Bussi, M., Palonta, F., Toma, S. Grafting in revision rhinoplasty. In: Acta Otorhinolaryngologicaltalica, 2013; 33(3), pp. 183-189.

[4] Jewell, M., Daunch, W., Bengtson, B. and Mortarino, E. (2015) The development of SERI® Surgical Scaffold, an engineered biological scaffold. In: Ann. N.Y. Acad. Sci., 1358, pp. 44-55.

[5] dos Sanos, V., Brandalise, R.N., Savaris, M., Biomaterials: Characteristics and properties, In: chapter in dos Sanos V., Brandalise R.N., Savaris M. Engineering of Biomaterials, Springer 2017.

[6] Furth, M.E., Atala, A., Future perspectives, In: chapter in Lanza R., Langer R., Vacanti J., Principles of Tissue Engineering, Third Edition, Elsevier Inc, 2007.

[7] Banyard, D.A., Bourgeois, J.M., Widgerow, A.D., Evans, G.R. Regenerative biomaterials: a review. In: Plast Reconstr Surg. 2015 Jun; 135(6), pp. 1740-8.

[8] Lee, H., Park, T.G., Design principles in biomaterials and scaffolds, In: chapter in Atala A., Lanza R., Thomson J., Nerem R., Principles of Regenerative Medicine, Elsevier 2008.

[9] Brown, B.N., Badylak, S.F. Extracellular matrix as an inductive scaffold for functional tissue reconstruction. In: Translational research: the journal of laboratory and clinical medicine, 2014; 163(4), pp. 268-285.

[10] Shahrokhi, S., Arno, A., Jeschke, M.G. The use of dermal substitutes in burn surgery: Acute phase. In: Wound Repair Regen, 2014; 22, pp. 14-22.

[11] Wainwright, D.J., Bury, S.B. Acellular dermal matrix in the management of the burn patient. In: Aesthet Surg. J. 2011; 31, pp. 13S-23S.

[12] Felder, J.M. 3rd, Goyal, S.S., Attinger, C.E. A systematic review of skin substitutes for foot ulcers. In: PlastReconstr Surg. 2012 Jul; 130(1), pp. 145-64. 
[13] Askari, M., Cohen, M.J., Grossman, P.H., Kulber, D.A. The use of acellular dermal matrix in release of burn contracture scars in the hand. In: PlastReconstr Surg. 2011; 127, pp. 1593-1599.

[14] Nathoo, R., Howe, N., Cohen, G. Skin substitutes: An overview of the key players in wound management. In: The Journal of Clinical and Aesthetic Dermatology. 2014; 7(10), pp. 44-48.

[15] Van Zuijlen, P., Gardien, K., Jaspers, M., et al. Tissue engineering in burn scar reconstruction. In: Burns \& Trauma, 2015; 3:18. doi:10.1186/s41038-015-0017-5.

[16] Oryan, A., Alidadi, S., Moshiri, A., Maffulli, N. Bone regenerative medicine: classic options, novel strategies, and future directions, In: Journal of Orthopaedic Surgery and Research, 2014 Mar 17; 9(1), p. 18.

[17] Cao, Z., Dou, C., Dong, S. Scaffolding biomaterials for cartilage regeneration, In: Journal of Nanomaterials, 2014, doi:10.1155/2014/489128

[18] Yang, G., Rothrauff, B.B., Tuan, R.S. Tendon and ligament regeneration and repair: clinical relevance and developmental paradigm. In: Birth defects research Part C, Embryo today: reviews, 2013; 99(3), pp. $203-222$.

[19] Mertens, J.P., Sugg, K.B., Lee, J.D., Larkin, L.M. Engineering muscle constructs for the creation of functional engineered musculoskeletal tissue. In: Regenerative medicine. 2014; 9(1), pp. 89-100.

[20] Pfister, B.J., Gordon, T., Loverde, J.R., Kochar, A.S., Mackinnon, S.E., Cullen, D.K. Biomedical engineering strategies for peripheral nerve repair: surgical applications, state of the art, and future challenges. In: Crit Rev Biomed Eng. 2011; 39(2), pp. 81-124.

[21] Ravi, S., Chaikof, E.L. Biomaterials for vascular tissue engineering. In: Regenerative medicine, 2010; 5(1), p. 107. doi:10.2217/rme.09.77.

[22] Chia, H.N., Wu, B.M. Recent advances in 3D printing of biomaterials. In: Journal of Biological Engineering. 2015; 9, p. 4. doi:10.1186/s13036-015-0001-4.

[23] Ma, P.X. Biomimetic materials for tissue engineering. In: Advanced drug delivery reviews, 2008; 60(2), pp. 184-198.

[24] Dvir, T., Timko, B.P., Kohane, D.S., Langer, R. Nanotechnological strategies for engineering complex tissues. In: Nature nanotechnology, 2011; 6(1), pp. 13-22.

[25] Liu, D., Yang, F., Xiong, F., Gu, N. The smart drug delivery system and its clinical potential. In: Theranostics, 2016; 6(9), pp. 1306-1323.

[26] Ferrari, M. Frontiers in cancer nanomedicine: directing mass transport through biological barriers. In: Trends in biotechnology, 2010; 28(4), pp. 181-188.

[27] Ullah, I., Subbarao, R.B., Rho, G.J. Human mesenchymal stem cells - current trends and future prospective. In: Bioscience Reports, 2015; 35(2):e00191. doi:10.1042/BSR20150025.

[28] Sabapathy, V., Sundaram, B., VM S., Mankuzhy, P., Kumar, S. Human Wharton's jelly mesenchymal stem cells plasticity augments scar-free skin wound healing with hair growth. In: Pant AB, ed. PLoS ONE. 2014; 9(4): e93726. doi:10.1371/journal.pone.0093726.

[29] King, N.M., Perrin, J. Ethical issues in stem cell research and therapy. In: Stem Cell Research \& Therapy. 2014; 5(4): 85. doi:10.1186/scrt474.

[30] Sabapathy, V., Kumar, S. hiPSC $\square$ derived iMSCs: NextGen MSCs as an advanced therapeutically active cell resource for regenerative medicine. In: Journal of Cellular and Molecular Medicine, 2016; 20(8), pp. 1571-1588.

[31] Choi, J.H., Gimble, J.M., Lee, K., et al. Adipose tissue engineering for soft tissue regeneration. In: Tissue Engineering Part B, Reviews, 2010; 16(4), pp. 413-426.

[32] Feisst, V., Meidinger, S., Locke, M.B. From bench to bedside: use of human adipose-derived stem cells. In: Stem Cells and Cloning: Advances and Applications, 2015; 8, pp. 149-162.

[33] Gimble, J.M., Bunnell, B.A., Guilak, F. Human adipose-derived cells: an update on the transition to clinical translation. In: Regenerative Medicine, 2012; 7(2), pp. 225-235.

[34] Schneider, S., Unger, M., van Griensven, M., Balmayor, E.R. Adipose-derived mesenchymal stem cells from liposuction and resected fat are feasible sources for regenerative medicine. In: European Journal of Medical Research, 2017; 22, p. 17. doi:10.1186/s40001-017-0258-9.

[35] Fisher, C., Grahovac, T.L., Schafer, M.E., Shippert, R.D., Marra, K.G., Rubin, J.P. Comparison of harvest and processing techniques for fat grafting and adipose stem cell isolation. In: PlastReconstr Surg. 2013; 132(2), pp. $351-61$.

[36] Dinescu S, Gălăţeanu B, Albu M, et al. Biocompatibility assessment of novel collagen-sericin scaffolds improved with hyaluronic acid and chondroitin sulfate for cartilage regeneration. In: BioMed Research International, 2013; doi:10.1155/2013/598056

[37] Dinescu, S., Galatean, B., Albu, M., Cimpean, A., Dinischiotu, A., Costache, M. Sericin enhances the bioperformance of collagen-based matrices preseeded with human-Adipose Derived Stem cells (hADSCs). In: International Journal of Molecular Sciences, 2013; 14(1), pp. 1870-1889.

[38] Tonnard, P., Verpaele, A., Peeters, G., Hamdi, M., Cornelissen, M., Declercq, H. Nanofat grafting: basic research and clinical applications. In: Plast Reconstr Surg. 2013; 132(4), pp. 1017-26.

[39] Mao AS, Mooney DJ. Regenerative medicine: Current therapies and future directions.In:Proceedings of the National Academy of Sciences of the United States of America, 2015; 112(47), pp. 14452-14459.

[40] Wong, H.K., Ivan Lam, C.R., Wen, F., Mark Chong, S.K., Tan, N.S., Jerry, C., Pal, M., Tan, L.P. Novel method to improve vascularization of tissue engineered constructs with biodegradable fibers. In: Biofabrication, 2016; 7; 8(1): 015004. doi: 10.1088/1758-5090/8/1/015004.

\section{Authors:}

ANDREEA GROSU-BULARDA, ALEXANDRU CHIOTOROIU, ELENA-LUMINITA STANCIULESCU

Emergency Clinical Hospital Bucharest, Romania

Corresponding author:

ALEXANDRU CHIOTOROIU

e-mail: chiotoroiu@yahoo.com 